\title{
Construct validity: Basic Psychological Needs Scale for Teachers
}

Rolando Angel-Alvarado ${ }^{1}$

Miguel R. Wilhelmi

Olga Belletich ${ }^{2}$

\author{
Journal for Educators, Teachers and Trainers, Vol. 12 (2)
}

\author{
https://jett.labosfor.com/
}

Date of reception: 15 Oct 2020

Date of revision: 12 Jan 2021

Date of acceptance: 18 April 2021

Rolando Angel-Alvarado, Miguel R. Wilhelmi, Olga Belletich(2021). Construct validity: Basic Psychological Needs Scale for Teachers. Journal for Educators, Teachers and Trainers, Vol. 12(2). 1 - 10.

${ }^{1}$ Instituto de Música, Universidad Alberto Hurtado, Santiago de Chile

${ }^{2}$ Departamento de Ciencias Humanas y de la Educación, Universidad Pública de Navarra, Pamplona, España 


\title{
Construct validity: Basic Psychological Needs Scale for Teachers
}

Rolando Angel-Alvarado ${ }^{1 *}$, Miguel R. Wilhelmi ${ }^{2}$, Olga Belletich ${ }^{2}$

${ }^{1}$ Instituto de Música, Universidad Alberto Hurtado, Santiago de Chile

${ }^{2}$ Departamento de Ciencias Humanas y de la Educación, Universidad Pública de Navarra, Pamplona, España

*Corresponding Author

Email ID: rolando.angel.alvarado@gmail.com

\begin{abstract}
Teacher autonomy encompasses pedagogical activities oriented towards planning, instruction, and assessment, as well as administrative tasks required by the education system. Therefore, it is imperative to focus research on teacher autonomy in specific tasks, using data collection procedures suitable to the context. In this study, the aim is to validate an original scale for collecting data on teacher autonomy in classroom settings under criteria established by Self-Determination Theory, in the framework of basic psychological needs. The method comprises a nonexperimental quantitative design, using a random cluster sample that is understood as a probability sampling because participant teachers only work in primary education levels. Results demonstrate that the scale possesses a strong degree of robustness regarding construction, application, and data collection. In conclusion, the validated scale identifies teacher autonomy as an explanatory variable in the model.
\end{abstract}

Keywords. Teacher autonomy, pedagogical competence, peer relatedness, scale validity, selfdetermination theory.

\section{INTRODUCTION}

In Spain, the Organic Law for the Improvement of Education Quality (LOMCE, which is the acronym in Spanish) was enacted to promote teacher autonomy (Ministerio de Educación, Cultura y Deporte [MECD], 2013). However, Sacristán (2014), Gairín (2015), and Prieto with Vilamor (2018) suggest that the opposite to the desired effect is achieved by LOMCE, disclosing a controversy between policy-making and educational practice. In light of this, it is imperative to design and validate a scale that measures teacher autonomy from the perspective of classroom settings, as it would serve to orient data analysis towards freedom in the curricular decision-making, dyadic interactions between teacher and learner, and the support relationships among colleagues.

In this study, we aim to establish the psychometric characteristics of the Basic Psychological Needs Scale for Teachers (BPNS-T) to determine the construct validity for basic psychological needs in the realm of classroom settings. Given this objective, procedures of exploratory and confirmatory factor analyses are executed throughout the study. Beyond technical matters, it is essential that BPNS-T is understood as an original scale, which has emerged in a research project focusing on teacher autonomy in classroom settings.

\section{Basic Psychological Needs}

Given that people tend to interact within a dynamic social structure (Deci \& Ryan, 2000), Self-Determination Theory (SDT) has established three basic psychological needs (Angel-Alvarado \& Álamos, 2018; Deci et al., 2001) that must be satisfied by environmental conditions (Ryan \& Deci, 2002), arising thus the key component techniques of need-support (Silva et al., 2014).

The first need is Autonomy, which involves the desire for choice and feeling of will during a specific activity (Uysal et al., 2010). Thus, the key component techniques consider the avoidance of control linked to authoritarian methods, respect-based environments, and decision-making capacity during conflictive situations (Reeve, 2009; Yu-Lan \& Reeve, 2011). Secondly, the Competence need is understood as the desire for optimal interaction within the workplace (Baard et al., 2004), focusing key component techniques towards the structure of work tasks, guided training, skill-related challenges, and constructive feedback (Haerens et al., 2013; Silva et al., 2014). Finally, Relatedness is the third need, which involves the feeling of connection with people or within the social environment (Van den Broeck et al., 2010) because it entails key component techniques linked to empathy, affection, dependability, and resources assisting (Silva et al., 2014).

SDT claims that the need for autonomy is essential for promoting self-determined behaviour - which is understood as the capacity to regulate conduct according to the perceived pleasure in the activity - because needs for competence and relatedness also can be satisfied in environments where controlled behaviour is promoted (Deci \& Ryan, 2000). In this way, SDT establishes the hypothesis that people show optimal engagement and 
psychological well-being only when feelings of competence and relatedness arise from autonomous behaviours (Ryan, 1993). Therefore, it is necessary to design scales that make it feasible to validate the construct of basic psychological needs, taking the autonomy need as the explanatory variable (Utts \& Heckard, 2015). In other words, the satisfaction of basic psychological needs is supported through the environmental promotion of autonomous behaviour (Angel-Alvarado et al., 2018; Gagné, 2009).

In the field of educational psychology, there are validated scales that are focused on basic psychological needs. Some of those scales consider the participation of secondary and undergraduate students (Chen et al., 2014; León et al., 2011; Sheldon et al., 2001; Vermeulen et al., 2012). However, 'there is not much research on the relation between the inner aspect of . . . need fulfillment and . . . teaching behavior' (Korthagen \& Evelein, 2016, p. 235) in the primary education system (Roth et al., 2007), secondary education (Abós et al., 2017; Taylor et al., 2008), and higher education (Brien et al., 2012, Sheldon et al., 2001). Particularly in the Spanish language, the lack of instruments reported by Korthagen and Evelein is more dramatic, given that the Spanish version of the Basic Psychological Needs at Work Scale (Abós et al., 2017) is the sole scale that possesses external validity, which is only oriented towards needs of teachers who work in secondary education schools. Therefore, it is imperative that an emerging scale be validated to explore the psychological needs of educators who impart lessons at the primary education levels.

\section{Design of the Basic Psychological Needs Scale for Teachers}

BPNS-T is validated by the same research team that has carried out the design, such that the construct validity is understood as a current and unprecedented process. The key component techniques of need-support have served to establish seven indicators in the scale (Haertel, 2013), with three corresponding to the variable of competence and two each for autonomy and relatedness variables. Specifically, the variable of autonomy implies teachers' freedom for making decisions about the curriculum and activities in the classroom; the competence variable encompasses teacher-student dyadic interactions; and lastly, the variable of relatedness considers emotional and trust relationships existent between teachers and workmates.

The construction of indicators is based on other basic psychological needs scales (Brien et al., 2012; Deci et al., 2001; Van den Broeck et al., 2010). We have to emphasise that the BPNS-T design is inspired by the Work Tasks Motivation Scale for Teachers (WTMST; Fernet et al., 2008), as it analyses the motivation from six different types of tasks, highlighting the teaching task in this current study. Therefore, BPNS-T is centred on classroom settings, measuring construct validity through the correlation between the variables of BPNS-T and WTMST.

A panel comprised of three experts has positively valued the appropriateness of the seven indicators of BPNS-T to data collection in compulsory education systems. Subsequently, a pilot study was carried out with 185 teachers participating who work in compulsory education levels. Those participants applied on BPNS-T through a Google form, disclosing the practical significance of factor loadings (Hair et al., 2014). Such findings were discussed at the European Conference on Educational Research (Angel-Alvarado et al., 2017). Due to all of the above, it is relevant to determine the statistical validity of BPNS-T in one education system, focusing on teachers who work in the system of primary education.

\section{METHOD}

This study corresponds to a nonexperimental quantitative design (Kerlinger \& Lee, 2002) as it aims to validate BPNS-T without provoking changes in data collection environments. Validity must be consistent with SDT, which means that the need for autonomy should be understood as an explanatory variable in the framework of basic psychological needs.

\section{Context}

Spain possesses linguistic diversity as some autonomous communities speak in a local tongue, in addition to Spanish, which is fostered officially through curriculum established by the respective autonomous community. Also, the Spanish education system has institutional diversity because there are public, private, and charter schools. Charter schools imply a mixture between public and private issues as, even when those schools are popularly known as private agencies, the state allocates public funding for their functioning. Finally, both generalist and specialist educators impart lessons in the Spanish system of primary education as the practicing teacher depends on obtaining a professional qualification for imparting a specific course (MECD, 2007; 2011).

\section{Sample}

The sample is comprised of 382 teachers, establishing as a common criterion that all participants impart subjects in the Spanish system of primary education. According to the UNESCO Institute for Statistics (2012 - 2018), the sample size has statistical representativeness because almost 383 teachers participated in this study. Three quantitative conditions were considered to calculate the sample size (Hair et al., 2015): the confidence level of $95 \%(\alpha=.05)$, expected error of $5 \%$, and proportion equivalent to $50 \%$. 
Teachers from all autonomous communities participated in data collection procedures, giving an account using a stratified random sample because participants have distributed in clusters. Thus, the sampling unit is nonprobabilistic (Mertler, 2016), such that diverse statistical techniques can be applied.

\begin{abstract}
Measures
Basic psychological needs. BPNS-T is an original scale, and its validity has been unpublished. It is focused on teachers' perception regarding their own satisfaction of the basic psychological needs for autonomy (two indicators; e.g., I can make decisions about my syllabus), competence (three indicators; e.g., I get on well with my students), and relatedness (two indicators; e.g., I like people I work with). Each indicator has been rated on a 5-point Likert-type scale, ranging from 1 (does not correspond at all) to 5 (absolutely correspond). The proposed scale's main weakness is observed in variables of autonomy and relatedness because two indicators were constructed in both cases, breaching the agreement of three indicators per variable in face validity (Lloret-Segura et al., 2014). It is important to indicate that the "face validity is the most basic and simple - and poor, in sense that it does not guarantee the statistical validity - . It refers mainly to the appearance of the instrument ... under a subjective judgement' (González, 2014, p. 230). In light of the above, the current study reports statistical outcomes concerning validity.

Teacher motivation. WTMST (Fernet et al., 2008) was translated to the Spanish language by Ruiz (2015), using in this study only the subscales of intrinsic motivation (three indicators; e.g., because it is pleasant to carry out this task), and identified regulation (three indicators; e.g., because I find this task important for the academic success of my students). Each indicator has been rated on a 7-point Likert-type scale, ranging from 1 (does not correspond at all) to 7 (absolutely corresponds). In this study, WTMST indicated a Cronbach's alpha equal to .76, such that it is acceptable because it is greater than .70 (Davenport et al., 2015). The Spanish version (Ruiz, 2015) of the WTMST (Fernet et al., 2008) was applied in this study centred on teaching activity. The goodnessof-fit was also acceptable (NFI $\geq .95 ; \mathrm{TLI} \geq .95 ; \mathrm{CFI} \geq .95 ; \& \mathrm{RMSEA} \leq .08)$.
\end{abstract}

\title{
Data Collection Procedures
}

In October 2017, an access link to a Google form was sent through email to schools situated in capital cities of each autonomous community from Spain. In this way, school administrations shared the access link with their teaching staff, via email.

All ethical codes suggested by the European Commission (European Union, 2013) for social research were ensured. That is, the data collection implied answering both scales and other demographical questions without gathering personal information from participants. Likewise, teachers decided by their own accord to participate in the current study, accepting some agreements of data confidentiality and anonymity previously through an informed consent, which was presented both in the email and within the Google form. Due to all of the above, the research group considers that all participants were competent to answer the scales, as they impart subjects in Spanish schools of primary education.

In November 2017, online access was closed permanently by the research group. Participants provided positive feedback regarding the research matter and the time required for answering the Google form.

\section{Data Analysis Procedures}

SPSS (with AMOS) is used in the validity process of the BPNS-T. Firstly, an exploratory factor analysis allows us to observe factor loadings of indicators and the internal reliability of the basic psychological needs through Cronbach's alpha, the composite reliability, and processes of convergent and discriminant validities to end up with the determination coefficient among response variables through multiple linear regression. The three basic psychological needs have been previously transformed in response variables to make plausible operational uses across the study. Subsequently, we carried out the model of Multiple Indicators Multiple Causes (MIMIC) to establish three effects: the language spoken by participants (Spanish or local tongue), the type of workplace (public school or charter school), and the teacher qualification (generalist or specialist in any field of knowledge). Finally, we evaluated the construct validity according to criteria of external validity, analysing correlations among response variables of BPNS-T with the variables established by the subscales from the Spanish version of the WTMST.

\section{RESULTS AND DISCUSSION}

Despite the fact that all factor loadings displayed practical significance (Hair et al., 2014), the structural matrix (Table 1) illustrates only factor loadings equal to or above \pm .70 as they provide significant and acceptable degrees of explanation in every variable (Furr, 2011). Likewise, communalities $\left(\mathrm{h}^{2}\right)$ were also accepted because they are equal to or above .50 and belowto .90 (Juárez-Nájera, 2015), such that the variance of variables achieved will be explained by their respective indicators. 
Table 1: Factor loadings, communalities $\left(\mathrm{h}^{2}\right)$ and percentage of variance in BPNS-T.

\begin{tabular}{|c|c|c|c|c|c|}
\hline \multirow{2}{*}{\multicolumn{2}{|c|}{ Item }} & \multicolumn{3}{|c|}{ Factor loadings } & \multirow[t]{2}{*}{$\mathrm{h}^{2}$} \\
\hline & & $\mathrm{AU}$ & $\mathrm{CO}$ & $\mathrm{RE}$ & \\
\hline AU1 & Me siento libre de enseñar de la manera que considere más apropiada & .83 & & & .68 \\
\hline AU2 & Puedo tomar decisiones sobre mi programa de asignatura & .84 & & & .70 \\
\hline $\mathrm{CO} 1$ & Los estudiantes dicen que soy bueno enseñando & & .70 & & .50 \\
\hline $\mathrm{CO} 2$ & Me llevo bien con mis estudiantes & & .73 & & .53 \\
\hline $\mathrm{CO} 3$ & Mis estudiantes me valoran y aprecian & & .90 & & .82 \\
\hline RE1 & Cuando comparto con gente de mi entorno laboral, confío en ellos & & & .89 & .80 \\
\hline \multirow[t]{7}{*}{ RE2 } & Me gusta la gente con la que trabajo & & & .76 & .58 \\
\hline & Cronbach Alpha & .82 & .80 & .81 & - \\
\hline & Convergent validity using Composite Reliability & .82 & .82 & .81 & - \\
\hline & Discriminant validity using AVE and MSV & & & & \\
\hline & FACTOR 1: AU & .69 & .21 & .22 & - \\
\hline & FACTOR 2: CO & & .61 & .16 & - \\
\hline & FACTOR 3: RE & & & .69 & - \\
\hline \multicolumn{5}{|c|}{$\begin{array}{l}\text { Extraction Method: Maximum Likelihood. } \\
\text { Rotation Method: Promax with Kaiser Normalisation. } \\
\text { Acronyms: AU = Autonomy; } \mathrm{CO}=\text { Competence; RE = Relatedness. }\end{array}$} & \\
\hline
\end{tabular}

The internal consistency was measured in each variable through Cronbach's alpha (Taber, 2017), which was contrasted with the composite reliability. Both coefficients displayed similar values because error covariances were not considered (Peterson \& Kim, 2013). The convergent validity was statistically demonstrated through the composite reliability and the average variance extracted (AVE) because the convergence is seen between indicators of every variable. The discriminant validity was also demonstrated statistically through AVE and the Maximum Shared Variance (MSV), as each indicator is interrelated only with one response variable.

Lastly, the need for autonomy was the variable that indicated the closest significant determination coefficient to one $\left(R^{2}=.64 ; p<.05\right)$. It is important to highlight that needs for competence $\left(R^{2}=.34\right)$ and relatedness $\left(R^{2}=.40\right)$ also show significant information $(p<.05)$ for explaining the satisfaction of basic psychological needs (Falk \& Miller, 1992). Thus, the need for autonomy is considered to be the explanatory variable (Utts \& Heckard, 2015) as it depends on other response variables to encourage the satisfaction of basic psychological needs. This finding is consistent with SDT because it accepts the SDT hypothesis that the need for autonomy is the explanatory variable in the model of basic psychological needs.

\section{MIMIC models of the effects of language, teacher qualification, and type of school}

In the confirmatory factor analysis (CFA), model 1a (Table 2) displays that measures of comparison (NFI, TLI, and CFI) possess acceptable goodness of fit, but parsimony measures (RMSEA) do not show the same trend. At this point, it is important to highlight that BPNS-T was designed to provide data concerning the satisfaction of teachers' basic psychological needs in classroom settings. Therefore, it is imperative to observe the performance of the scale under environmental criteria, such as spoken language (Spanish or local), type of school (public or charter), and professional qualification for working as a teacher (generalist or specialist).

Thus, from model 2 until model 4, measures of comparison indicate excellent goodness of fit, as values are equal or above to .95. The parsimony measure is also excellent because it displays values equal to or below .08 in RMSEA. That being said, environmental criteria may be analysed in the Spanish system of primary education through BPNS-T, considering the following effects:

Spoken language difference. All basic psychological needs indicate significant differences $(p<.05)$ among teacher groups in classroom settings. Concretely, in needs for autonomy and relatedness, educators who impart lessons in the local tongue $\left(R^{2 \mathrm{AU}}=.74 ; R^{2 \mathrm{RE}}=.41\right)$ show higher levels of satisfaction than peers who teach in the Spanish language $\left(R^{2 \mathrm{AU}}=.46 ; R^{2 \mathrm{RE}}=.36\right)$. However, teachers who only speak Spanish display a higher level of satisfaction in the need for competence $\left(R^{2 \mathrm{CO}}=.35\right)$ than natives who speak in their local tongue $\left(R^{2 \mathrm{CO}}=.33\right)$.

Type of school differences. Basic psychological needs indicate significant differences $(p<.05)$ in classroom settings. Teachers who impart lessons in public and charter schools show the same satisfaction level in the need for autonomy $\left(R^{2 \mathrm{AU}}=.64\right)$. However, educators who teach in public schools display a higher level of satisfaction in the need for competence $\left(R^{2 \mathrm{CO}}=.30\right)$ than the other group $\left(R^{2 \mathrm{CO}}=.21\right)$, and in contrast, those who work in charter schools show a higher level of fulfilment in the need for relatedness $\left(R^{2} \mathrm{RE}=.74\right)$ than teachers who impart lessons in public schools $\left(R^{2} \mathrm{RE}=.33\right)$. 
Teacher qualifications differences. Generalist teachers indicate higher satisfaction levels in all basic psychological needs $\left(R^{2 \mathrm{AU}}=.70 ; R^{2} \mathrm{RE}=.49 ; R^{2 \mathrm{CO}}=.35\right)$ than the group comprised of specialist educators. All observed differences between teacher groups in classroom settings are significant $(p<.05)$.

Given these outcomes, we recommend applying the BPNS-T in studies contextualised in the Spanish system of primary education because it has been validated using environmental criteria linked to linguistic diversity, types of school, and teacher qualifications. Consequently, the statistical reliability has been demonstrated in the construction, application, and data collection.

Table 2: Fit indices for the MIMIC models in the BPNS-T.

\begin{tabular}{|c|c|c|c|c|c|c|c|}
\hline & & $\chi^{2}$ & df & NFI & TLI & CFI & RMSEA \\
\hline \multicolumn{8}{|c|}{ Model 1- Total sample CFA model } \\
\hline & 3-factor model & 46.7 & 11 & .95 & .94 & .97 & .09 \\
\hline & 6-factor model & 183.9 & 89 & .93 & .95 & .96 & .05 \\
\hline \multicolumn{8}{|c|}{ Model 2 -CFA spoken language; invariance of the 3-factors } \\
\hline a. & No invariance & 54.8 & 22 & .95 & .94 & .97 & .06 \\
\hline b. & Factor loadings (FL) & 57.6 & 26 & .95 & .95 & .97 & .06 \\
\hline c. & FL + Factor Variances (FV) & 60.9 & 33 & .95 & .97 & .97 & .05 \\
\hline & $\mathrm{FL}+\mathrm{FV}+$ Factor Covariances (FC) & 67.8 & 39 & .94 & .97 & .97 & .04 \\
\hline \multicolumn{8}{|c|}{ Model 3 -CFA type of school; invariance of the 3 -factors } \\
\hline & No invariance & 59.3 & 22 & .94 & .93 & .96 & .07 \\
\hline b. & FL & 67.6 & 26 & .94 & .93 & .96 & .07 \\
\hline c. & $\mathrm{FL}+\mathrm{FV}$ & 71.5 & 33 & .93 & .95 & .96 & .06 \\
\hline & $\mathrm{FL}+\mathrm{FV}+\mathrm{FC}$ & 77.3 & 39 & .93 & .96 & .96 & .05 \\
\hline \multicolumn{8}{|c|}{ Model 4-CFA teacher qualification; invariance of the 3-factors } \\
\hline a. & No invariance & 65.9 & 22 & .94 & .92 & .96 & .07 \\
\hline b. & FL & 70.9 & 26 & .94 & .93 & .96 & .07 \\
\hline & $\mathrm{FL}+\mathrm{FV}$ & 86.6 & 33 & .92 & .94 & .95 & .07 \\
\hline & $\mathrm{FL}+\mathrm{FV}+\mathrm{FC}$ & 105.7 & 39 & .91 & .93 & .94 & .07 \\
\hline
\end{tabular}

From the model 2 to model 4, the letter a expresses observed outcomes during the comparative analyses and said differences were eliminated progressively across letters b, c and d. The last letter reports no distinctions. Source: Own elaboration.

\section{Construct validity based on external validity criteria}

Variables concerned with the WTMST' Spanish version (Ruíz, 2015) were incorporated into the model because external validity serves to establish a degree of robustness to the construct validity (Brewer \& Grano, 2014). In the model, the categories of intrinsic motivation and identified regulation, which are included on the selfdetermination continuum (Gagné \& Deci, 2005; Howard et al., 2017), indicating acceptable indices in goodness of fit (Table 2, Model 1b).

In Table 3, the need for autonomy is identified again as the explanatory variable for the satisfaction of basic psychological needs, given that it indicates the closest significant determination coefficient to one. In contrast, needs for competence and relatedness were substantially satisfied. Most of the basic psychological needs displayed moderate positive correlations with intrinsic motivation and identified regulation, excepting the need for relatedness, as it reported weak positive correlations with both SDT categories. Specifically, the need for competence indicated the highest significant correlations with SDT categories, which is consistent with the reviewed literature because the competence is associated with the knowledge that teachers apply concretely in classroom settings (Klassen et al., 2012; Korthagen \& Evelein, 2016; Marshik et al., 2017; Pelletier et al., 2002). These statistical results demonstrate that all basic psychological needs have the same importance in SDT as they are intertwined (Dysvik et al., 2013; González-Cutre et al., 2016; Niemiec \& Ryan, 2009; Ryan \& Deci, 2000; Sheldon et al., 2001). Thus, findings corroborate the SDT hypothesis because people show an optimal engagement and psychological well-being only when feelings of competence and relatedness arise from autonomous behaviours (Ryan, 1993). Therefore, the satisfaction of the need for autonomy is vital for reaching self-determined behaviours (Angel-Alvarado et al., 2018; Gagné, 2009; Sataloff \& Davidson, 2012).

Table 3: Determination coefficients (R2) and Pearson correlations among basic psychological needs and external validity criteria.

\begin{tabular}{|l|l|l|l|l|l|}
\hline Basic Psychological Needs & $\mathrm{R}^{2}$ & $\mathrm{CO}$ & $\mathrm{RE}$ & $\mathrm{IM}$ & $\mathrm{IR}$ \\
\hline Autonomy & $.65^{*}$ & $.40^{*}$ & $.51^{*}$ & $.46^{* *}$ & $.44^{* *}$ \\
\hline Competence (CO) & $.33^{*}$ & - & $.38^{*}$ & $.53^{* *}$ & $.49^{* *}$ \\
\hline Relatedness (RE) & $.40^{*}$ & - & - & $.27 * *$ & $.27 * *$ \\
\hline
\end{tabular}




\begin{tabular}{|l|l|l|l|l|l|}
\hline Intrinsic Motivation (IM) & $.61 *$ & - & - & - & .99 \\
\hline Identified Regulation (IR) & $.81 *$ & - & - & - & - \\
\hline$* p<.05 ; * * p<.01$ \\
Source: Own elaboration. \\
Source \\
\hline
\end{tabular}

Finally, external validity criteria demonstrated that each basic psychological need has a particular and significant influence on intrinsic motivation (Phillippe \& Vallerand, 2008; Ryan \& Deci, 2006) and identified regulation (Ryan \& Deci, 2017). Specifically, the depth internalisation of the identified regulation has positive effects on teacher satisfaction of basic psychological needs (Orsini et al., 2016), affecting even students' interpersonal development and the assimilation of social representations as, for instance, implications of high scores on exams or tests (Cheon et al., 2018). Consequently, BPNS-T allows us to carry out a multidimensional analysis of basic psychological needs, displaying an acceptable consistency with motivational categories of the SDT (Dysvik et al., 2013).

\section{CONCLUSION}

SDT establishes the hypothesis that people show optimal engagement and psychological well-being only when feelings of relatedness and competence arise from autonomous behaviours, such that the need for autonomy takes a determinant role among the three basic psychological needs. The validity procedure of BPNS-T displays consistency with the theoretical framework of the SDT, as it ratifies the need for autonomy as the explanatory variable in the construct of basic psychological needs, in the realm of classroom settings. In other words, the SDT hypothesis is proven statistically. In any case, both the theoretical contributions and external validity of BPNS-T depend on incorporating other analytical measures from the SDT such as, for instance, the self-determination continuum.

In conclusion, BPNS-T has been validated statistically in the Spanish context because it collected reliable data concerning basic psychological needs in the system of primary education. The scale validity demonstrates, through external validity criteria, the construct validity of basic psychological needs once the need for autonomy was identified as the construct's explanatory variable. That is to say, autonomy depends on competence and relatedness to foster the satisfaction of basic psychological needs.

These findings provide reliability to BPNS-T as a scale because, statistically, factor loadings in each indicator are significant and acceptable. The internal consistency also displays acceptable values, and correlations with external variables are significant. In addition to this, the goodness-of-fit indicates acceptable indices through MIMIC models, suggesting some prospective lines of research for the Spanish system of primary education as significant differences are observed between teacher clusters in matters centred on spoken language (Spanish or local tongue), type of workplace (public school or charter school), and teacher qualifications (generalist or specialist).

Finally, the application of BPNS-T is recommended for studies contextualised in the Spanish system of primary education and considering observed values in different statistical procedures; perhaps it would be convenient to replicate the present study in other educational environments, either in Spain or other countries. Nonetheless, it would be opportune to incorporate at least one indicator in variables of autonomy and relatedness to improve the face validity, which should report similar factor loadings to indicators presented herein to increase the degree of robustness of the proposed scale.

\section{ACKNOWLEDGEMENT}

This work was funded by the National Agency for Research and Development (ANID) / Scholarship Program / DOCTORADO BECAS CHILE/2015 [grant number: 72160356].

\section{REFERENCES}

1. Abós, A., Sevil, J., Julián, J., Martín-Albo, J., \& García-González, L. (2017). Spanish validation of the Basic Psychological Needs at Work Scale: A measure to predict teachers' well-being in the workplace. International Journal for Educational and Vocational Guidance, (2), 127-148. https:/ / doi.org/10.1007/s10775-017-9351-4

2. Angel-Alvarado, R., \& Álamos, J. (2018). Dirección musical en el conjunto de guitarras Guitárregas: Un liderazgo centrado en la autodeterminación del profesorado de música. Revista Internacional de Educación Musical, (6), 53-61. https://doi.org/10.1177/230748411800600105

3. Angel-Alvarado, R., Belletich, O., \& Wilhelmi, M. R. (2017). Teachers in Spain and their satisfaction of the three innate psychological needs: A study of Self-Determination Theory. Paper presented at the European Conference on Educational Research from European Educational Research Association. Copenhagen, Dinamarca.

4. Angel-Alvarado, R., Cisternas, M., Molina, J., \& San Martín, V. (2018). Formación inicial de educadoras preescolares: Una experiencia centrada en la autodeterminación de la infancia 
$\begin{array}{lllll}\text { preescolar. Infancia, Educación } y \text { Aprendizaje, } & \text { 4(2), }\end{array}$ https://doi.org/10.22370/ieya.2018.4.2.1058

5. Baard, P., Deci, E., \& Ryan, R. (2004). Intrinsic need satisfaction: A motivational basis of performance and well-being in two work settings. Journal of Applied Social Psychology, 34, 20452068. https://doi.org/10.1111/j.1559-1816.2004.tb02690.x

6. Brewer, M., \& Grano, W. (2014). Research design and issues of validity. In H. Reis \& C. M. Judd (Eds.), Handbook of research methods in social and personality psychology (pp. 11-26). Cambridge University Press.

7. Brien, M., Forest, J., Mageau, G., Boudrias, J., Desrumaux, P., Brunet, L., \& Morin, M. (2012). The basic psychological needs at work scale: Measurement invariance between Canada and France. Applied Psychology: Health and Well-Being, 4(2), 167-187. https://doi.org/10.1111/j.17580854.2012.01067.x

8. Chen, B., Vansteenkiste, M., Beyers, W., Boone, L., Deci, E., Van der Kaap-Deeder, J., ... Verstuyf, J. (2015). Basic psychological need satisfaction, need frustration, and need strength across four cultures. Motivation and Emotion, 39(2), 216-236. https://doi.org/10.1007/s11031-014-9450-1

9. Cheon, S. H., Reeve, J., Lee, Y., \& Lee, J. (2018). Why autonomy-supportive interventions work: Explaining the professional development of teachers' motivating style. Teaching and Teacher Education, 69, 43-51. https://doi.org/10.1016/j.tate.2017.09.022

10. Davenport, E. C., Davison, M., Liou, P., \& Love, Q. (2015). Reliability, dimensionality, and internal consistency as defined by Cronbach: Distinct albeit related concepts. Educational Measurement: Issues and Practice, 34(4), 4-9. https:// doi.org/10.1111/emip.12095

11. Deci, E. \& Ryan, R. (2000). The "What" and "Why" of Goal Pursuits: Human Needs and the SelfDetermination of Behavior. Psychological Inquiry, 11(4), 227-268. https://doi.org/10.1207/S15327965PLI1104_01

12. Deci, E., Ryan, R., Gagné, M., Leone, D., Usunov, J., \& Kornazheva, B. (2001). Need satisfaction, motivation, and well-being in the work organizations of a former Eastern Bloc country: A crosscultural study of self-determination. Personality and Social Psychology Bulletin, 27(8), 930-942. https://doi.org/10.1177/0146167201278002

13. Dysvik, A., Kuvaas, B., \& Gagné, M. (2013). An investigation of the unique, synergistic and balanced relationships between basic psychological needs and intrinsic motivation. Journal of Applied Social Psychology, 43(5), 1050-1064. https://doi.org/10.1111/jasp.12068

14. European Union (2013). Ethics for researchers: Facilitating research excellence in FP7. Publications Office of the European Union.

15. Falk, R., \& Miller, N. (1992). A Primer for Soft Modeling. University of Akron Press.

16. Fernet, C., Senécal, C., Guay, F., Marsh, F., \& Dowson, M. (2008). The work tasks motivation scale for teachers (WTMST). Journal of Career Assessment, 16(2), 256-279. https:// doi.org/10.1177/1069072707305764

17. Furr, R. (2011). Scale construction and psychometrics for social and personality psychology. SAGE.

18. Gagné, M. (2009). A model of knowledge-sharing motivation. Human Resource Management, 48(4), 571-589. https:// doi.org/10.1002/hrm.20298

19. Gagné, M., \& Deci, E. L. (2005). Self-determination theory and work motivation. Journal of Organizational Behavior, 26(4), 331-362. https://doi.org/10.1002/job.322

20. Gairín, J. (2015). Autonomy and school management in the Spanish context. Educational, Cultural and Psychological Studies, (11), 103-117. https://doi.org/10.7358/ecps-2015-011-gair

21. González, A. (2014). Características técnicas de los instrumentos de medida desde la teoría clásica de los tests. Fiabilidad y validez. In C. Martínez (Coord.), Técnicas e instrumentos de recogida y análisis de datos (pp. 213-240). Universidad Nacional de Educación a Distancia.

22. González-Cutre, D., Sicilia, A., Sierra, A. C., Ferriz, R., \& Hagger, M. S. (2016). Understanding the need for novelty from the perspective of self-determination theory. Personality and Individual Differences, 102, 159-169. https:// doi.org/10.1016/j.paid.2016.06.036

23. Haerens, L., Aelterman, N., Van den Berghe, L., De Meyer, J., Soenens, B., \& Vansteenkiste, M. (2013). Observing physical education teachers' need-supportive interactions in classroom setting. Journal of Sport \& Exercises Psychology, 35(1), 3-17. https://doi.org/10.1123/jsep.35.1.3

24. Haertel, E. (2013). Getting the help we need. Journal of Educational Measurement, 50(1), 84-90. https://doi.org/10.1111/jedm.12002

25. Hair, J., Black, W., Babin, B., \& Anderson, R. (2014). Multivariate Data Analysis. Pearson Education. 
26. Hair, J., Wolfinbarger, M., Money, A. H., Samouel, P., \& Page, M. J. (2015). Essentials of bussiness research methods. Routledge.

27. Howard, J., Gagné, M., \& Bureau, J. (2017). Testing a continuum structure of self-determined motivation: A meta-analysis. Psychological Bulletin, 143(12), 1346-1377. https://doi.org/10.1037/bul0000125

28. Instituto de Estadísticas de la UNESCO (2012 - 2018). Education: Teachers by teaching level of education. UIS. Stat.

29. Juárez-Nájera, M. (2015). Exploring sustainable behavior structure in higher education: A sociopsychology confirmatory approach. Springer.

30. Kerlinger, F., \& Lee, H. (2002). Investigación del comportamiento: Métodos de Investigación en Ciencias Sociales. McGraw-Hill Interamericana.

31. Klassen, R., Perry, N., \& Frenzel, A. (2012). Teachers' relatedness with students: An underemphasized component of teachers' basic psychological needs. Journal of Educational Psychology, 104(1), 150-165. https://doi.org/10.1037/a0026253

32. Korthagen, F., \& Evelein, F. (2016). Relations between student teachers' basic needs fulfillment and their teaching behavior. Teaching and Teacher Education, 60, 234-244. https://doi.org/10.1016/j.tate.2016.08.021

33. León, J., Domínguez, E., Núñez, J., Pérez, A., \& Martín-Albo, J. (2011). Traducción y validación de la versión española de la Échelle de Satisfacción des Besoins Psychologiques en el contexto educativo. Anales de Psicología, 27(2), 405-411.

34. Lloret-Segura, S., Ferreres-Traver, A., Hernández-Baeza, A., \& Tomás-Marco, I. (2014). El Análisis Factorial Exploratorio de los Ítems: una guía práctica, revisada y actualizada. Anales de Psicología, 30(3), 1151-1169. https://doi.org/10.6018/analesps.30.3.199361

35. Marshik, T., Ashton, P. T., \& Algina, J. (2017). Teachers' and students' needs for autonomy, competence, and relatedness as predictors of students' achievement. Social Psychology of Education, 20(1), 39-67. https://doi.org/10.1007/s11218-016-9360-z

36. MECD. (2007). Orden ECI/3857/2007, de 27 de diciembre, por la que se establecen los requisitos para la verificación de los títulos universitarios oficiales que habiliten para el ejercicio de la profesión de Maestro en Educación Primaria. Boletín Oficial del Estado, (312), 53747-53750.

37. MECD. (2011). Real Decreto 1027/2011, de 15 de julio, por el que se establece el Marco Español de Cualificaciones para la Educación Superior. Boletín Oficial del Estado, (185), 87912-87918.

38. MECD. (2013). Ley Orgánica 8/2013, de 9 de diciembre, para la mejora de la calidad educativa. Boletín Oficial del Estado, (295), 97858-97921.

39. Mertler, C. A. (2016). Introduction to educational research. SAGE.

40. Niemiec, C., \& Ryan, R. (2009). Autonomy, competence, and relatedness in the classroom: Applying self-determination theory to educational practice. Theory and Research in Education, 7, 133-144. https://doi.org/10.1177/1477878509104318

41. Orsini, C., Evans, P., Binnie, V., Ledezma, P., \& Fuentes, F. (2016). Encouraging intrinsic motivation in the clinical setting: teachers' perspectives from the self-determination theory. European Journal of Dental Education, 20(2), 102-111. https:// doi.org/10.1111/ eje.12147

42. Pelletier, L. G., Séguin-Lévesque, C., \& Legault, L. (2002). Pressure from above and pressure from below as determinants of teachers' motivation and teaching behaviors. Journal of Educational Psychology, 94(1), 186-196. https://doi.org/10.1037/0022-0663.94.1.186

43. Peterson, R. A., \& Kim, Y. (2013). On the relationship between coefficient alpha and composite reliability. Journal of Applied Psychology, 98(1), 194-198. https://doi.org/10.1037/a0030767

44. Phillippe, F., \& Vallerand, R. (2008). Actual environments do affect motivation and psychological adjustment: A test of self-determination theory in a natural setting. Motivation and Emotion, 32, 8189. https://doi.org/10.1007/s11031-008-9087-z

45. Prieto, M., \& Villamor, P. (2018). El impacto de una Reforma: Limitación de la autonomía, estrechamiento de la libertad y erosión de la participación. Archivos Analíticos de Políticas Educativas, 26(63), 1-32. https://doi.org/10.14507/epaa.26.3255

46. Reeve, J. (2009). Why teachers adopt a controlling motivation style toward students and how they can become more autonomy supportive. Educational Psychologist, 44(3), 159-175. https://doi.org/10.1080/00461520903028990 
47. Roth, G., Assor, A., Kanat-Maymon, Y., \& Kaplan, H. (2007). Autonomous motivation for teaching: How self-determined teaching may lead to self-determined learning. Journal of Educational Psychology, 99(4), 761-774. https:// doi.org/10.1037/0022-0663.99.4.761

48. Ruíz, M. (2015). Soporte de autonomía y motivación en educación: Consecuencias a nivel global y contextual (Doctoral Thesis, Universitas Miguel Hernández, Elche, Spain).

49. Ryan, R. M. (1993). Agency and organization: Intrinsic motivation, autonomy and the self in psychological development. In J. Jacobs (Ed.), Nebraska symposium on motivation: Developmental perspectives on motivation (pp. 1-56). University of Nebraska Press.

50. Ryan, R., \& Deci, E. (2000). Intrinsic and extrinsic motivations: Classic definitions and new $\begin{array}{llll}\text { directions. } & \text { Contemporary Educational }\end{array}$ https://doi.org/10.1006/ceps.1999.1020

51. Ryan, R., \& Deci, E. (2002). An overview of self-determination theory: An organismic-dialectical perspective. In E. Deci, \& R. Ryan (Eds.), Handbook of self-determination research (pp. 3-33). University of Rochester Press.

52. Ryan, R. \& Deci, E. (2006). Self-regulation and the problem of human autonomy: Does psychology need choice, self-determination, and will? Journal of Personality, 74, 1557-1585. https://doi.org/10.1111/j.1467-6494.2006.00420.x

53. Ryan, R., \& Deci, E. (2017). Self-Determination Theory: Basic psychological needs in motivation, development, and wellness. The Guilford Press.

54. Sacristán, J. G. (2014). La LOMCE. ¿Una ley más de educación? Revista Interuniversitaria de Formación del Profesorado, 81(28.3), 31-44.

55. Sataloff, R., \& Davidson, J. (2012). The older singer. En G. E. McPherson, \& G. F. Welch (Eds.), The Oxford handbook of music education (pp. 610-625). Oxford University Press.

56. Sheldon, K., Elliot, A., Kim, Y., \& Kasser, T. (2001). What is satisfying about satisfaying event? Testing 10 candidate psychological needs. Journal of Personality and Social Psychology, 80, 325-339. https://doi.org/10.1037//O022-3514.80.2.325

57. Silva, M., Marques, M., \& Teixeira, P. (2014). Testing theory in practice: The example of selfdetermination theory-based interventions. The European Health Psychologist, 16(5), 171-180.

58. Taber, K. (2017). The use of Cronbach's alpha when developing and reporting research instruments in Science Education. Research in Science Education, 1-24. https://doi.org/10.1007/s11165-016-9602-2

59. Taylor, I., Ntoumanis, N., \& Standage, M. (2008). A self-determination theory approach to understanding the antecedents of teachers' motivational strategies in physical education. Journal of Sport \& Exercise Psychology, 30, 75-94.

60. Utts, J., \& Heckard, R. (2015). Mind on statistics. Cengage Learning.

61. Uysal, A., Lee, H., \& Knee, C. (2010). The role of need satisfaction in self-concealment and wellbeing. Personality and Social Psychology Bulletin, 36(2), 187-199. https://doi.org/10.1177/0146167209354518

62. Van den Broeck, A., Vansteenkiste, M., De Witte, H., Soenens, B., \& Lens, W. (2010). Capturing autonomy, competence, and relatedness at work: Construction and initial validation of the workrelated basic need satisfaction scale. Journal of Occupational and Organizational Psychology, 83, 9811002. https:// doi.org/10.1348/096317909X481382

63. Vermeulen, M., Castelijns, J., Kools, Q., \& Koster, B. (2012). Measuring student teachers' basic psychological needs. Journal of Education for Teaching: International Research and Pedagogy. https://doi.org/10.1080/02607476.2012.688556

64. Yu-Lan, S., \& Reeve, J. (2011). A meta-analysis of the effectiveness of intervention programs designed to support autonomy. Educational Psychology Review, 23(1), 159-188. https://doi.org/10.1007/s10648-010-9142-7 